\title{
Cross-border cooperation projects as a community development generator - „Adriatic Canyoning“ project
}

\author{
Ivan Jurilj \\ Office for European Integration of the Government of WHC, LLB \\ ivan@eui-zzh.ba
}

\begin{abstract}
This paper shows how cross-border cooperation projects can play a significant role in the development of the local community and be an extremely important factor in launching new initiatives in the local community, if they are prepared taking into account certain critical factors. The case study of the "Adriatic Canyoning" project shows the key factors that enable a project to become a generator of development in the local community. Even in the case where the project has a tourist character, it can be a driver of infrastructural or urban development. The crucial role for a project to acquire such a character is the context of project preparation, the relationship between project objectives and planned activities, as well as the context of the project within the strategic development goals of a specific community. Also, the cross-border character of the project gives an additional dimension, not only in the transfer of knowledge and experience from cross-border regions, but also gives weight to a broader perspective that a particular local need gains through cross-border cooperation.
\end{abstract}

Key words: Cross-border cooperation, projects, generator of development, local and regional development

\section{Projekti prekogranične suradnje kao generator razvoja zajednice - projekt „Adriatic Canyoning“}

Sažetak: Ovaj rad prikazuje kako projekti prekogranične suradnje mogu odigrati značajnu ulogu u razvoju lokalne zajednice i biti izuzetno važan čimbenik u pokretanju novih inicijativa u lokalnoj zajednici ukoliko su pripremljeni uzimajući u obzir određene ključne čimbenike. Kroz studiju slučaja projekta „Adriatic Canyoning“ prikazat će se koji su to ključni čimbenici koji omogućuju da jedan projekt postane generator razvoja u lokalnoj zajednici. Čak i u slučaju kada projekt ima turistički karakter može biti pokretač infrastrukturnog ili urbanog razvoja. Presudnu ulogu da jedan projekt dobije takav karakter jesu kontekst pripreme projekta, međusobni odnos ciljeva projekta i planiranih aktivnosti, kao i sam kontekst projekta u okviru strateških ciljeva razvoja neke specifične zajednice. Također, prekogranični karakter projekta daje dodatnu dimenziju, ne samo u prijenosu znanja i iskustva iz prekograničnih regija, već daje težinu šire perspektive koju određena lokalna potreba dobiva kroz prekograničnu suradnju.

Ključne riječi: prekogranična suradnja, projekti, generator razvoja, lokalni i regionalni razvoj 
Jurilj, I.

Cross-border cooperation projects as a community development generator „Adriatic Canyoning“ project

\section{INTRODUCTION}

This paper aims to contribute to a better understanding of the role of development projects financed from various EU programs, but also from other programs available to Bosnia and Herzegovina, and to direct further research in order to help stakeholders in need of such projects to approach preparation of their projects for open calls in a higher-quality way.

Bosnia and Herzegovina has the opportunity to participate in numerous European Union programs such as the Instrument for Pre-Accession Assistance (IPA II) ${ }^{1}$, and various community programs that provide an opportunity to meet certain needs or solve certain problems through financial support for these programs. The main instruments for implementation of these programs are projects financed through these programs, which are implemented by different institutions, organizations or companies depending on the eligibility and in compliance with the criteria of individual programs. However, it is often the case that it not understood to a sufficient degree how these projects work, and therefore, either there are not enough applicants for these programs, or the projects are not of sufficient quality, and in the end the projects that are not approved do not result in the effects that were originally planned by the program. Therefore, it is exceptionally important to understand the philosophy of the project approach in order for the results to be visible and in order to fulfill the purpose of the program, and equally to meet the primary need of the end user, which is supposed to be the original motive for applying with a project to an open call.

Considering the status of Bosnia and Herzegovina in the context of European integrations and readiness to absorb funds, Bosnia and Herzegovina's access to European Union funds is limited. Therefore, in the context of end users coming from local or regional areas, cross-border cooperation programs are exceptionally important, so in this paper the emphasis will primarily be on these programs.

\section{METHODS AND MATERIALS}

The development of this paper is based on two key approaches to problem analysis. Namely, it uses a theoretical explanation of the problem by analyzing and consulting available information based on existing research and results. The problem analysis mostly relied on secondary data sources that included various publications such as studies, manuals, Internet sources, official data of certain institutions and the like.

In addition to the theoretical argumentation and analysis based on secondary data sources, the paper is based on the results of a specific project "Adriatic Canyoning" through the example of which the key performance factors and challenges that can be encountered in project preparation and implementation are analyzed. Namely, the paper is based on an experiential example of project writing and direct communication with key stakeholders during preparation, as well as during implementation of the project.

The paper was developed using the methods considered to be best capable of contributing to the analysis of the problem and elaboration of key recommendations, such as comparative method, analysis and synthesis method, case study, and method of direct conversation with key stakeholders.

\footnotetext{
${ }^{1}$ The Instrument for Pre-Accession Assistance is a program aimed at candidate and potential candidate countries for membership in the European Union in order to prepare and adapt for full membership in the EU. The programs are adopted for a seven-year financial period. The current program is the IPA program 2014-2020 or popularly called IPA II, while the IPA program 2007-2013 was previously in effect.
} 
Jurilj, I.

Cross-border cooperation projects as a community development generator „Adriatic Canyoning“ project

\section{STUDY RESULTS}

European Territorial Cooperation is one of the objectives of the European Union's cohesion policy. Territorial cooperation provides a framework for implementation of joint measures and policies at the local, regional and state levels. The overall objective of territorial cooperation is to ensure balanced economic, social and territorial development of the European Union, in order to reduce the negative impact of borders and balance socio-economic connectedness.

Territorial cooperation is based on three main directions of cooperation: cross-border cooperation, transnational cooperation and interregional cooperation. Bosnia and Herzegovina can participate in transnational and cross-border cooperation, while interregional cooperation is concerned only with members of the European Union, Norway and Switzerland, and in certain programs such as URBACT in Iceland and Liechtenstein.

\subsection{Cross-border cooperation programs and Bosnia and Herzegovina}

According to the European Commission's Implementing Regulation No. 447/2014, establishing an IPA II Instrument for Pre-Accession Assistance for the period 2014-2020, three types of cross-border cooperation programs are distinguished:

- cross-border cooperation between one or more member states of the European Union and one or more beneficiaries of the IPA II instrument,

- cross-border cooperation between two or more IPA II beneficiaries,

- cross-border cooperation between IPA II instrument beneficiaries and countries within the framework of the European Neighborhood Instrument.

In accordance with its status, Bosnia and Herzegovina can participate in all these programs through six special cross-border cooperation programs with a total value of slightly more than 630 million euros, as follows:

- One Trilateral Cross-Border Cooperation Program (Croatia - Bosnia and Herzegovina - Montenegro), i.e. cross-border cooperation between one or more EU member states and one or more IPA II beneficiary countries.

- Two bilateral cross-border cooperation programs (Bosnia and Herzegovina Montenegro and Bosnia and Herzegovina - Serbia), i.e. cross-border cooperation programs between two or more IPA II beneficiary countries,

- Three transnational cross-border cooperation programs (Danube Cross-Border Cooperation Program, Adriatic-Ionian Cross-Border Cooperation Program - ADRION and Mediterranean Cross-Border Cooperation Program - MED), i.e. cross-border cooperation between IPA II instrument beneficiary countries and European Neighborhood Instrument countries.

Although all these cross-border cooperation programs are exceptionally important for Bosnia and Herzegovina, the most interesting for local and regional stakeholders are bilateral cross-border cooperation programs Bosnia and Herzegovina - Serbia, and Bosnia and Herzegovina - Montenegro, as well as the trilateral cross-border cooperation program Croatia - Bosnia and Herzegovina - Montenegro in the total amount of about 80 million euros. This is mainly due to the fact that these programs cover an area with the same or similar crossborder needs and challenges. Also, unlike transnational cross-border cooperation programs, bilateral cross-border cooperation programs, in terms of their content, enable the financing of more tangible activities, or they may include a certain part of infrastructure works, i.e. they may also contain an investment component. It is important to note here that projects from cross-border cooperation programs are not infrastructural or investment projects by their nature. However, the inclusion of infrastructure works in projects, especially at the local level, 
Jurilj, I.

Cross-border cooperation projects as a community development generator „Adriatic Canyoning“ project

greatly contributes to the visibility of project interventions and contributes to better achievement of the final results of projects in the field.

In the following, we will present three key cross-border cooperation programs that are of key interest to local and regional stakeholders in Bosnia and Herzegovina.

Trilateral cross-border cooperation program Croatia - Bosnia and Herzegovina Montenegro 2014-2020: Trilateral cross-border cooperation program Croatia - Bosnia and Herzegovina - Montenegro is of exceptional importance for Bosnia and Herzegovina, especially because its scope covers most of Bosnia and Herzegovina and allows a large number of local and regional stakeholders to apply with their project. The program covers the area of 12 counties in the Republic of Croatia, Brčko District and 109 municipalities and cities in Bosnia and Herzegovina, and 10 municipalities and cities in Montenegro. The total value of the program is 67.2 million euros, of which $85 \%$ is from the budget of the European Union, and $15 \%$ is co-financing by program beneficiaries.

The general objective of the Croatia - Bosnia and Herzegovina - Montenegro crossborder cooperation program is to strengthen the social, economic and territorial development of the cross-border area through the implementation of joint projects and activities. The program consists of four priority axes:

- Priority Axis 1 - Improving the quality of services in public health and the social welfare sector. The specific objective of this thematic axis is to improve the quality of services in public health and the social welfare sector.

- Priority Axis 2 - Protecting the environment and nature, improving risk prevention and promoting sustainable energy and energy efficiency. The specific objectives of this thematic axis are the promotion and improvement of nature protection systems and risk prevention systems and the promotion of use of renewable energy sources and energy efficiency.

- Priority Axis 3 - Contribution to the development of tourism and preservation of cultural and natural heritage. The specific objectives of this thematic axis are strengthening and diversification of the tourist offer through cross-border access and better management and sustainable use of cultural and natural heritage.

- Priority Axis 4 - Strengthening competitiveness and developing the business environment in the program area. The specific objective of this thematic axis is to support the development of infrastructure and services of institutions for the purpose of encouraging competitiveness and developing the business environment in the program area.

The cross-border cooperation program Bosnia and Herzegovina - Montenegro 20142020: The cross-border cooperation program Bosnia and Herzegovina - Montenegro is smaller than the Trilateral cross-border cooperation program Croatia - Bosnia and Herzegovina - Montenegro, but is equally important in the context of needs of local and regional stakeholders. The program covers an area of 56 municipalities in Bosnia and Herzegovina, while the program area in Montenegro consists of 14 municipalities. The total value of the program is 9.7 million euros, of which $83 \%$ is from the EU budget while $13 \%$ is co-financing by program beneficiaries.

The general objective of the program is sustainable development in the cross-border area between Bosnia and Herzegovina and Montenegro, which will be promoted through the implementation of joint projects, based on the effective use of comparative advantages of the program area. The program consists of three thematic priorities that further elaborate the general objective of the program: 
Jurilj, I.

Cross-border cooperation projects as a community development generator „Adriatic Canyoning“ project

- Thematic priority 1: Promotion of employment, labor mobility and social and cultural inclusion across the border. The specific objectives of this thematic priority are improved access to the labor market and the environment for generating new jobs and increased opportunities for employment and social inclusion of vulnerable groups.

- Thematic priority 2: Environmental protection, promotion of adaptation to and mitigation of climate change, risk prevention and management. The specific objectives of this thematic priority are Management and energy efficiency of local water supply systems, wastewater and solid waste systems and environmental protection are improved by cross-border coordination and joint activities and improved climate change adaptation and mitigation measures, as well as risk prevention and management measures.

- Thematic priority 3: Promoting tourism, cultural and natural heritage. The specific objective of this thematic priority is to improve the quality and diversity of the tourist offer that is based on natural and cultural heritage.

This program belongs to the category of cross-border cooperation programs that are concerned only with cooperation between two or more IPA II beneficiaries, and therefore the project application and implementation procedures are adapted to the rules and regulations for financing external assistance of the European Union. The fact that in the first public call under this program there were not enough quality projects to use all the funds provided for the first call indicates how important is the readiness and capacity of potential applicants to participate in these programs.

The cross-border cooperation program Bosnia and Herzegovina - Serbia 2014-2020: By its character, the cross-border cooperation program Bosnia and Herzegovina - Serbia is the same as the previous program, except that it is directed to another program area. The program covers an area of 60 municipalities and cities and the Brčko District in Bosnia and Herzegovina and 30 municipalities in Serbia. The total value of the program is slightly more than 16.2 million euros, of which $85 \%$ is allocated from the EU budget, and $15 \%$ is cofinancing by beneficiaries from $\mathrm{BiH}$ and Serbia.

The general objective of the program is to strengthen socio-economic development in the cross-border area between the Republic of Serbia and Bosnia and Herzegovina, through the implementation of targeted and specific measures based on comparative advantages of the program area and joint efficient use of resources. The program is divided into three thematic priorities which are elaborated in more detail in specific objectives of the measure and potential projects:

- Thematic priority 1: Stimulating employment, labor mobility, social and cultural inclusion across the border. The specific objectives of this thematic priority are to improve the employability of labor and increase employment opportunities, and to encourage social and economic inclusion.

- Thematic priority 2: Protecting the environment, encouraging adaptation to and mitigation of climate change, risk prevention and management. The specific objectives of this thematic priority are to improve sustainable planning in the area of environmental protection and to promote biodiversity, and to advance the management system for emergency interventions.

- Thematic priority 3: Promoting tourism and cultural and natural heritage. The specific objectives of this thematic priority are to increase the contribution of tourism to the socio-economic development of the program area and to strengthen the cultural identity of the program area. 
Jurilj, I.

Cross-border cooperation projects as a community development generator „Adriatic Canyoning“ project

\subsection{Significance of cross-border cooperation programs for Bosnia and Herzegovina}

Bosnia and Herzegovina has limited access to EU funds, which depends on the readiness of Bosnia and Herzegovina to access certain programs, i.e. on compliance with the specific criteria or conditions that Bosnia and Herzegovina should meet. The access of Bosnia and Herzegovina to European Union funds was made possible through the Instrument for PreAccession Assistance 2014-2020, which is also the main instrument to support the implementation of reforms. Namely, the Instrument for Pre-Accession Assistance for the period from 2014 to 2020 (“IPA II") supports beneficiaries in adopting and implementing the political, institutional, legal, administrative, social and economic reforms which these beneficiaries need in order to achieve conformity with the European Union values and to gradually align with the rules, standards, policies and practices of the European Union with a view to membership in the European Union.

In addition to IPA II, Bosnia and Herzegovina, based on the Agreement between the European Community and Bosnia and Herzegovina on the general principles for the participation of Bosnia and Herzegovina in Community programs, may access a number of specific programs subject to meeting specific requirements for the particular program, such as Horizon 2020, Cosme, Europe for Citizens, Creative Europe etc. In relation to these programs, cross-border cooperation programs have great significance for Bosnia and Herzegovina from the viewpoint of local and regional stakeholders in the border area to which these programs are primarily intended. Cross-border cooperation programs not only provide access to financial resources, but also provide added value through the establishment of cross-border partnerships.

However, since cross-border cooperation programs are normally implemented in partnership of two or more partners from two or more countries, the preparation of these projects is all the more complex than projects implemented within one country. Preparing cross-border cooperation projects requires a greater dose of creativity, openness, communicativeness, and drive, as well as flexibility because your need must fit into the wider context, and find a common connection with the needs of your partners. To that extent, before preparation of the project and before invitation of tenders, it is important to become familiar with the content of the cross-border cooperation program and the goals intended to be achieved by the program itself.

The importance of cross-border cooperation and its effects is also indicated by the experiences of regions and local communities from the European Union that have been beneficiaries of cross-border cooperation programs. Regions and local communities that were beneficiaries of cross-border cooperation programs are mostly more developed regions, e.g. Istria County in the Republic of Croatia, which has drawn experiences through cross-border cooperation with regions from Italy and Slovenia. Cross-border cooperation projects can be used as a basis for other development activities within a local community, region or even a state. It is precisely in this context that the importance of cross-border cooperation programs is crucial. Namely, cross-border cooperation programs cannot solve the issue of the development of a region or community, but cross-border cooperation projects can be a generator of development and a basis for development initiatives. Considering that Bosnia and Herzegovina is bounded by a border with three states, the Republic of Croatia, Montenegro and Serbia, and can directly participate in cross-border cooperation programs with these countries, it is all the more important to recognize the potential of cross-border cooperation and use its maximum opportunities. Also, in addition to bilateral cross-border cooperation programs, a great opportunity lies in transnational cross-border cooperation programs that can bring new energy, new ideas and new prospects. 
Jurilj, I.

Cross-border cooperation projects as a community development generator „Adriatic Canyoning“ project

\subsection{Some of the key factors for a successful cross-border cooperation project}

Cross-border cooperation projects represent a kind of challenge in relation to the conventional approach to project preparation and implementation. As compared to a project being implemented at a single location and being related exclusively or almost exclusively to one or more partners at that location (municipality, region, or country), cross-border cooperation projects are usually related to several partners in several countries. Therefore, there is always a challenge of how to find a common link in different countries with different partners who have different interests and needs, to guide them through the preparation and later also through the implementation of the project. In this respect, the preparation of a project proposal requires a slightly different approach than for projects that take place within a single community.

The key factors in the context of the preparation of cross-border cooperation projects can be summarized in the following elements:

- Project preparation should begin long before the project writing. Preparation of a project proposal does not begin with the writing of the project application. Project preparation begins long before opening of the public call to which a project proposal is planned to be submitted. Project preparation, in addition to administrative issues such as feasibility studies, permits, etc., also involves preparation of the environment in which the project will be implemented. This means that the main stakeholders must be prepared to understand the context of the project long before the project begins to be implemented, and that the need for the project is created in the community, in order for the project implementation to be accepted by local stakeholders to the maximum extent possible.

- A good knowledge of both the narrower and the wider context is required. Quality project preparation requires a good understanding of the local context and local needs that are focused, not only on what the project will address, but also on what the project implementation will affect, or what long-term changes will occur if the project is successfully implemented. Similarly, recognizing a wider context allows us to fit our needs into a wider framework and show how our project can contribute to the wider environment. Also, a good understanding of the specific program, or what is intended to be achieved with the program, will make it easier for us to understand the specific needs of the program area and how the needs of our community can fit into the needs of the program area.

- Multidimensionality of cross-border cooperation projects. Cross-border cooperation projects are characterized by multidimensionality, which is usually reflected through several components of a project such as education, public campaigns, research, infrastructure investments, and promotional activities. In order for a project to be effective and if we want to achieve the maximum effect of the project, these different components of the project must be implemented in synergy and must be in good interaction with each other. For example, infrastructure investments will not have the necessary effect if they are not accompanied by activities such as public campaigns, lectures or promotional activities.

- Openness, drive and flexibility. These three elements are the necessary preconditions to successfully prepare, and after approval to successfully implement, a cross-border cooperation project. Communities or organizations that do not have elements of openness, drive and flexibility are unlikely to find a partner or partners and are unlikely to fit some of their needs or problems into a wider context. Therefore, open, driving and flexible organizations have the most success in attracting funds from cross-border programs. 
Jurilj, I.

Cross-border cooperation projects as a community development generator „Adriatic Canyoning“ project

\subsection{Case study - "Adriatic Canyoning" project}

The previously explained success factors will be presented through a practical example of the Adriatic Canyoning project, which is co-financed by the European Union within the Trilateral Cross-border Cooperation Program Croatia - Bosnia and Herzegovina Montenegro. The Adriatic Canyoning project is an example of a complex cross-border project that has brought together six different partners from three different countries (Croatia, Bosnia and Herzegovina and Montenegro). The project partners were the town of Široki Brijeg as the project coordinator and the municipality of Grude from Bosnia and Herzegovina, the towns of Obrovac and Drniš, and the Development Agency ZADRA NOVA from the Republic of Croatia, and the Agency for Development and Infrastructure of Herceg Novi from Montenegro as project partners. Each of the partners had its own specific needs and activities, which are nevertheless integrated into common goals and represent a single project.

The general objective of the Adriatic Canyoning project is focused on strengthening and diversifying the tourist offer in the Adriatic hinterland through a cross-border approach in order to enable better management and sustainable use of natural and cultural heritage. The thus formulated project objective was preceded by numerous analyses and preparations long before the opportunity for project financing appeared. Although the goal of a project is usually formulated by associating it with the goals of the program from which it is financed, the goal of the project reflects the essence of the project if the goal definition was preceded by a detailed analysis and understanding of the situation and context. For example, for two different projects the general goal of each project can be formulated in the same way, however, the elaboration of the goal is completely different depending on the context of the project. It is therefore very important that the institution that is the project coordinator understands all the necessary elements regardless of whether the project is elaborated by an external expert. Otherwise, when an external expert prepares the project without the project coordinator organization fully understanding the context of the project, regardless of the quality of the written project, there will be a problem with project implementation.

Preparation of the Adriatic Canyoning project began as early as three years before the project idea was prepared in the form of application for an open tender. This is especially important from the perspective of project relevance. The relevance of the project is presented through a brief analysis of the context. Namely, the Adriatic hinterland is a region with a rich natural and cultural heritage and is characterized by a strong regional identity. Taking into account the natural attractions and karst landscape, the Adriatic hinterland is suitable for the development of outdoor and adventure tourism. Despite this potential, the Adriatic hinterland is still not fully integrated into the overall tourist offer. In the Adriatic hinterland there are many sites that can attract tourists, but prior to that they need to be equipped, promoted and ready for tourists. However, there are some good examples of sites that have developed such a tourist offer and are known even worldwide, such as the Cetina River Canyon, NP Paklenica, etc. Since in Herzegovina and Montenegro there are still no such attractions that are part of an active tourist offer, the Adriatic Canyoning project is intended to transfer the knowledge and experience to new specific sites in Dalmatia and Herzegovina (4 canyons: Zrmanja and Čikola in Dalmatia and Peć Mlini and Borak in Herzegovina), as well as in a specific location in the hinterland of Herceg Novi (Orjen and Vrbanj). Through the project, these sites are equipped with specific tourist infrastructure, as well as accompanying tourist facilities and promoted as part of the unique ADRIATIC OUTDOOR tourist destination.

As active tourism attracts more and more people, the Adriatic Canyoning project is expected to integrate these rural areas and mobilize local stakeholders, especially young people, to start their own businesses and thus stay in the area. The project will contribute to 
Jurilj, I.

Cross-border cooperation projects as a community development generator „Adriatic Canyoning“ project

the diversity of the tourist offer that is now lacking throughout the area, especially in the rural interior part of the Adriatic hinterland.

The Adriatic Canyoning Project also fits into a broader context. The project is in conformity with the overall tourism policy of the European Union, which is particularly concerned with the new political framework for tourism in Europe - "Europe, the world's number one tourist destination". The Adriatic Canyoning project directly contributes to the competitiveness of European tourism and the competencies defined in the Lisbon Treaty. The project is also in conformity with the external dimension of the European Union's tourism policy.

\subsubsection{Cross-border character of the Adriatic Canyoning project}

Although the individual activities of the Adriatic Canyoning project can be carried out locally and regionally, i.e. independently from country to country, the full effect can be achieved only if this project is implemented jointly and thus different regions and different sites are integrated into a single tourist offer.

The sites that are part of the project are located in three different countries, but they are part of a single tourist region - the Adriatic hinterland. In addition, tourism is not something that can be promoted only locally, especially if it is aimed at international tourists. To this end, it is necessary to develop and promote a joint tourist offer and place it as such on the international market.

Tourists targeted by this tourist offer come from all over Europe and one local community or region cannot achieve its full effects by acting alone. In this regard, it is necessary to jointly promote a specific tourist offer, and not to promote it independently (locally). The analysis of the situation confirmed that it is necessary to enrich and diversify the tourist offer at different sites in these three regions and thus further promote the Adriatic hinterland as a great destination for adventure tourism. The Adriatic hinterland has the potential to be one of the most attractive destinations for adventure tourism, offering different types of outdoor tourism and an experience that is available not only to professionals but also to the general population. Considering that the Zadar County in the Republic of Croatia is already recognized for this type of tourist offer (NP Paklenica, Velebit, etc.) and has a great experience in tourism development, through the Adriatic Canyoning project it transferred its knowledge and experience to cross-border partners in Bosnia and Herzegovina and Montenegro that did not have such experience and knowledge.

\subsubsection{Cross-border project as a generator of development}

Cross-border cooperation projects are typically not investment projects and cannot be exclusively focused on infrastructure investments. Some programs, such as transnational cross-border cooperation programs, almost completely exclude infrastructure investments except in exceptional cases. Unlike transnational programs, cross-border cooperation programs, where IPA II beneficiary countries are involved, i.e. the programs explained in the previous chapter, may include infrastructure investments, although they cannot be the basis of the project.

Starting from the meaning of a cross-border cooperation program, which aims to ensure balanced economic, social and territorial development of the European Union, and in order to reduce the negative impact of borders and balance socio-economic connectedness, the investment or infrastructure component of a project is exceptionally important for IPA II 
Jurilj, I.

Cross-border cooperation projects as a community development generator „Adriatic Canyoning“ project

beneficiary countries. Namely, a project that contains an investment component, or that includes some infrastructural investments, has better effects on the local community and helps to fulfill the primary objective of the project. Infrastructure investments in cross-border cooperation programs are in a way aimed at project promotion.

On the example of the Adriatic Canyoning project, we can see that most of the project is focused on infrastructure investments, without the project being an investment project in its essence. Namely, through the Adriatic Canyoning project, the sites of Borak in Široki Brijeg and Peć Mlini in Grude have been infrastructurally developed. The Sajmište park in Široki Brijeg is improved in urban planning terms, but only due to the fact that the park is a key component of the tourist offer related to Borak. Likewise, the Peć Mlini site and Ravlića cave in Grude have been infrastructurally improved because in this way these sites have become an integral part of the tourist offer and have become interesting to the tourist market.

These two sites can serve as an example of how one project that is not essentially an infrastructure project can absorb most of the project into infrastructure investments. Likewise, these infrastructural investments have contributed to a completely new perception by the local community of tourism and the opportunities that these sites have in tourism. Also, investments through the Adriatic Canyoning project have initiated new investments in urban planning of these sites, which still would not have happened had the Adriatic Canyoning project not made a positive change in the perception of the local community.

The example of the Adriatic Canyoning project shows the significance of a project implemented through a cross-border cooperation program. For example, if the infrastructural development of the Sajmište park in Široki Brijeg was done independently, or from the town budget, the effect would not be even close to the effect when the park is infrastructurally developed within the project which develops a specific tourist offer in the entire area of the Adriatic hinterland. The reason for this is the context of the project, because the park is no longer just a park but is embraced by the community as something more than the park itself, i.e. the park has the role of promoting tourist content and tourist identifiability. However, the basis of the Adriatic Canyoning project in the case of Široki Brijeg is not the infrastructural development of the park, even though the development of the park absorbed most of the investments, but the focus of the project is the development of adventure tourist infrastructure related to the park: zip-line, free climbing platform. canyoning, and the park is only a secondary infrastructure that contributes to better recognizability of the new tourist content.

\section{CONCLUSION}

The advantage of projects financed from cross-border cooperation programs or other programs in relation to conventional financing from the budget is that projects financed from cross-border cooperation programs contribute to a wider and more significant change in the local community, so even smaller interventions can affect or start larger investments or initiatives. The reason for this is precisely the context of project implementation, where our project acquires a much broader and more significant dimension than when we implement it independently or from our own budget. Therefore, the philosophy of projects financed from cross-border cooperation programs or other similar programs is to be the drivers and generators of the development of a local community or region.

Therefore, the approach to the preparation of cross-border cooperation projects must be different and must be based on the factors described above that can contribute to the success of the project. Openness, flexibility, drive, readiness for change, connectedness, are 
Jurilj, I.

Cross-border cooperation projects as a community development generator „Adriatic Canyoning“ project

the basis for successful preparation of cross-border cooperation projects and the prerequisite for a project to achieve the maximum effect after implementation.

\section{REFERENCES}

1. European Territorial Cooperation "Building Bridges Between People", European Commission, Directorate-General for Regional Policy, Brussels, 2014

2. Communication from the Commission to the European Parliament, the Council, the European Economic and Social Committee and the Committee of the Regions

3. Regulation of the European Parliament and of the Council no. 231/2014 establishing an Instrument for Pre-Accession Assistance (IPA II),

4. Commission Implementing Regulation 447/2014 on the specific rules for implementing Regulation (EU) No. 231/2014 of the European Parliament and of the Council establishing an Instrument for Pre-Accession Assistance (IPA II),

5. Framework agreement between the European Community and $\mathrm{BiH}$ on general principles for the participation of Bosnia and Herzegovina in Community Programs ("Official Gazette of $\mathrm{BiH}$ - International Agreements", No. 15/06),

6. Project proposal "Adriatic Canyons Adventure Tours - Adriatic Canyoning",

7. Interreg IPA Cross-border Cooperation Program Croatia - Bosnia and Herzegovina Montenegro 2014-2020 - https://www.interreg-hr-ba-me2014-2020.eu/

8. Cross-border Cooperation Program BiH - Montenegro - http://cbc.bih-mne.org/

9. Cross-border Cooperation Program Serbia - BiH - https://srb-bih.org/en/

10. Adriatic-Ionian Transnational Cooperation Program 2014-2020 (Interreg ADRION) https://www.adrioninterreg.eu/

11. Interreg Danube Transnational Cooperation Program 2014-2020 - http://www.interregdanube.eu/

12. Interreg Mediterranean Transnational Cooperation Program 2014-2020 (Interreg MED) https://interreg-med.eu/

13. Cross-border cooperation - benefiting from borders, MINISTRY FOR FOREIGN AFFAIRS OF FINLAND, 2011

14. Practical Guide to Cross-border Cooperation, Third Edition 2000, Association of European Border Regions (AEBR)

15. www.dei.gov.ba

16. www.ec.europa.eu 